\title{
The remittances of migrant Tongan and Samoan nurses from Australia John Connell ${ }^{1}$ and Richard PC Brown*2
}

\author{
Address: ${ }^{1} \mathrm{Head}$ of School, School of Geosciences, University of Sydney, Australia and ${ }^{2}$ School of Economics, The University of Queensland, \\ Brisbane, Australia \\ Email: John Connell - jconnell@mail.usyd.edu.au; Richard PC Brown* - r.brown@economics.uq.edu.au \\ * Corresponding author
}

Published: 13 April 2004

Human Resources for Health 2004, 2:2

This article is available from: http://www.human-resources-health.com/content/2/l/2

(C) 2004 Connell and Brown; licensee BioMed Central Ltd. This is an Open Access article: verbatim copying and redistribution of this article are permitted in all media for any purpose, provided this notice is preserved along with the article's original URL.

\begin{abstract}
Background: Migration and remittances are of considerable importance in the small Pacific island states. There has been a significant migration of skilled health workers in recent decades to metropolitan fringe states, including Australia and New Zealand. This paper reports the findings of a re-analysis of survey of Samoan and Tongan migrants in Australia where the sample is split between nurse households and others.
\end{abstract}

Methods: The study analyzes the survey data with a view to comparing the remittance behaviour and determinants of remittances for nurses and other migrant households, using both descriptive, cross-tabulations and appropriate econometric methods.

Results: It is found that a significantly higher proportion of nurse households sent remittances home, and, on average remitted more. Remittances of nurse households did not decline significantly over time contrary to what has generally been predicted. This was in contrast to other migrant households in the sample, for whom remittances showed a sharp decline after 15 years absence. Remittances contribute much more to the income of migrant sending countries, than the cost of the additional human capital in nurse training.

Conclusions: Given the shortage of nurses in Australia and New Zealand, and therefore the high demand for immigrant nurses, investment by Pacific island governments and families in nurse training constitutes a rational use of economic resources. Policies encouraging investment in home countries may be more effective than policies directly discouraging brain drain in contributing to national development.

\section{Background}

In little more than a quarter of a century there has been extensive migration from the small states of the Pacific to the metropolitan countries that border the region, resulting in absolute population decline in some states and new social, political and economic relationships. Contemporary variations in the structure of migration are substantially a function of colonial history, and throughout the
Pacific islands, islanders have mobilized colonial ties to emigrate to the metropolitan countries. In small states like the Cook Islands, Niue and American Samoa there are more islanders overseas than in their own countries, and that overseas proportion is gradually increasing. For the larger Polynesian states of Tonga and Samoa (formerly Western Samoa) that are discussed here, there are as many Tongans and Samoans overseas as there are in the home 
countries. Migration is both catalyst and consequence of economic and social change.

In the small island states of the Pacific, prospects for economic growth are quite limited. Hence the now widely perceived disparities in economic welfare between the Pacific states, especially the smallest states of Polynesia and Micronesia, and the fringing metropolitan nations, have contributed not only to substantial migration but also to increasing pressures for further migration. The variety of reasons put forward to explain migration in the Pacific sometimes seems interminable and the problems of generalization considerable. However the major influences are economic even where social changes are also significant. Migration is primarily a response to real and perceived inequalities in socio-economic opportunities that are themselves a result of dependent and/or uneven sectoral and regional development. A major influence on migration has been radical changes in expectations over what constitutes a satisfactory standard of living, a desirable occupation and a suitable mix of accessible services and amenities. Social influences on migration are important, especially in terms of access to education and health services; such social influences are in turn often a function of economic issues. Migration remains, in different forms, a time-honoured strategy of moving from a poor area to a richer one in the search for social and economic mobility abroad or at home.

In all migration contexts, remittances play an important role. By 1995 total remittances exceded total foreign aid flows and represent approximately $40 \%$ of global Foreign Direct Investment. Remittances, projected by the World Bank to exceed US $\$ 90$ billion in 2003, constitute the largest source of financial flows to developing countries and are considered more stable than other flows such as foreign direct investment and foreign aid [1]. In the past remittances attracted the interest of some policy-makers and researchers, including the ILO, as a potential net social benefit of international labor movements. The importance of migrants' remittances as a major source of external finance for developing countries has only recently received serious attention from international financial institutions such as the World Bank Kapur and McHale note "remittances have emerged as the latest cause célèbre among governments, foundations, and multilateral institutions" [2]. The World Bank, Department for international Development (DFID, UK) and the International Migration Policy Programme (IMP) hosted a twoday conference in London on 9-10 October 2003: 'The International Conference on Migrant Remittances: Development Impact, Opportunities for the Financial Sector and Future Prospects', bringing together over 100 participants from 42 countries.
(See http://www.livelihoods.org/hot topics/migration/ remittances.html).

Latin America and the Caribbean receive the largest share of remittances, with US $\$ 25$ billion in 2002. South Asia receives approximately US $\$ 16$ billion. Relative to GDP, South Asia is the largest recipient with remittance receipts amounting to $2.5 \%$ of GDP. In Africa, one striking example is Lesotho, where remittances comprise $25 \%$ of GDP. In the South Pacific, two countries that are most dependent on migration and remittances although tiny countries in terms of population and GDP are Tonga and Samoa, where income from remittances is estimated to be about the same as total GDP.

However in many situations there is inadequate information on remittances and their use, and hence on their real and potential contribution to domestic economic development and their influence on social change or continuity. In many countries migrant remittances form a significant part of disposable income, especially in Tonga, Samoa and smaller states such as Cook Islands, Wallis and Futuna, Kiribati and Tuvalu. The sustainability of remittance-dependent development is particularly important, but also uncertain because the needs of the countries of origin for remittances are likely to grow faster than supply $[3,4]$. The rate of growth of migration to major destinations, namely New Zealand, Australia and the USA, has declined in recent years due to economic recession, and return migration has sometimes been considerable. Even with continued migration however the anticipated imbalance is likely to persist because of the dynamics of settlement migration. With family reunification and with greater integration of the migrants in the host communities, their ability and willingness to remit has been widely expected to decline over time.

In some contexts in the region international migration has been viewed as a kind of "safety-valve" reducing pressures on national governments to provide employment opportunities and welfare services especially in conditions of high rates of natural increase of population and low rates of economic growth. Throughout the region, the "safetyvalve" effect, limited economic growth plus concern over individual freedom of movement, have combined to result in steady and domestically unimpeded migration from many countries. In Tonga and Samoa this has led to the domestic population total being relatively unchanged for several decades, despite relatively high rates of natural increase. Migration has tended to be viewed rather as a substitute for development than as a short-term support for increasing the effectiveness of national development efforts. The use of remittances is therefore of considerable significance. 
Samoa is one of the larger of the Polynesian states. With a population of about 170,000 , two thirds of whom are on the island of Upolu (the smaller of the two main islands), which contains the only town, Apia, and has the national hospital. Samoa has a small open economy, dependent on a narrow resource base centred on agriculture and fishing, and also on tourism, aid and remittances. It has a health system that has been substantially affected by the large-scale emigration of trained personnel. 'Whilst there have been significant numbers of Samoan doctors trained since independence, losses of doctors to other countries in the region and to rim countries continues to be a major problem', hence in 1991 most Samoan doctors practising in the public system were either of retirement age (15 out of 34) or new graduates ( 8 of the 34 being aged less than 35 ) and accounted for only $60 \%$ of all public sector doctors, with most of the remainder being United Nations Volunteer doctors. Several doctors had actually been brought back from retirement to cope with the shortage [5]. This unusually skewed age distribution has not subsequently changed.

It was argued at the start of the 1990s that 'Many new graduates have not been satisfied with salaries offered and have acquired more remunerative positions elsewhere. According to one 1992 estimate, some 50\% of medical graduates migrated over the period 1958-1991 with $80 \%$ of this loss occurring since 1980' [5]. Similar problems of retention were evident for other skilled health workers, including nurses, and were attributed 'to salary levels offered by the government relative to alternative employment opportunities in the region and rim countries' [5]. However the number of nurses was then regarded as adequate, though there was a shortage by 1998 when there were only 140 nurses working at the National Hospital (compared with the required staff number of 168). This situation has persisted.

The Kingdom of Tonga is a Polynesian state with a population of just under 100,000 but, in parallel with Samoa, almost as many ethnic Tongans live overseas. The economy of Tonga has grown steadily in recent years, with agriculture and fisheries being important, but, like Samoa, it is heavily dependent on aid and remittances. Because of the distribution of Tonga's population over some forty populated islands Tonga's health system is more complex and decentralized than in most island states. However since about $70 \%$ of the country's population now live on the main island of Tongatapu the central Vaiola hospital plays a crucial role in health delivery, though there are three other regional hospitals. A small private sector meets the needs of some expatriates and those who are willing to pay in order to avoid hospital queues. As in Samoa, medical officers are trained overseas, usually in Papua New
Guinea, Fiji or New Zealand, whilst the training of Health Officers and nurses takes place locally.

The international migration of skilled health workers, and especially the loss of skilled workers from developing states, has become an issue of global concern in recent years. Though the brain drain of nurses and doctors was well recognised as of concern in the 1970s, at that time it was concentrated in relatively few states, such as the Philippines and some smaller island states in the Caribbean [6]. Subsequently it has become significant in many developing states, especially the relatively poor sub-Saharan states, and in other small island states, where wages are relatively poor and employment conditions sometimes difficult [7]. While this process is part of an accelerated globalisation of the service sector, marked by a new internationalisation of labour, it poses problems for less developed states. In many of these states health conditions are particularly difficult and the loss of skilled health workers is a substantial constraint to effective health care delivery.

Migration of skilled health workers from the Pacific island countries is widely considered to be a growing problem. Loss of significant numbers of key health workers affects core national strategies for health sector development, creating problems for health care and for human resource planning and development. Training of skilled workers is particularly costly because of the long duration, the high costs of teaching materials and techniques (and the need for post-graduate education and training programmes) and the limited resources of island states. Consequently the outmigration of health workers is unusually costly. Replacements may also be costly (and may be lacking in appropriate skills, languages and cultural sensitivity), thus creating potential problems in satisfying basic needs, achieving sustainable health strategies and developing healthy islands.

Migration has become more selective over time, as metropolitan states have moved towards migration policies that favour skilled migration, so migration from Pacific island states is more likely to be characterised as a brain drain. A significant part of this migration has been of nurses, doctors and other skilled health workers. Like other migrants such skilled health workers also play a role in sending remittances to their home countries. The present study was designed to provide some indication of the structure of remittance flows from skilled health workers from Tonga and Samoa who were living in Australia to their home island states. A specific study of this kind has never previously focused on health workers, other than in the case of migrant doctors from the Philippines, where it was concluded that their remittances were substantial enough to offset training and other costs [8]. The present study represents a re-examination, and more detailed analysis 
by sector, of data collected in 1994 on the migration of Samoans and Tongans to the two Australian cities of Sydney and Brisbane. Though some data were collected on doctors and other skilled health workers only the sample of nurses was large enough to generate meaningful data and conclusions, hence this report focuses entirely on nurses.

\section{Methods and literature review The survey}

In 1994 a total of 1,294 households from the Tongan and Samoan communities in Brisbane and Sydney were surveyed. This sample represented about $15 \%$ to $20 \%$ of the Tongan- and Samoan-born population in Australia as estimated from the 1991 Australian census. The precise population size of the Tongan and Samoan migrant community in Australia is unknown (in part because of mis-reporting, the significant proportion of illegal migrants and the New Zealand citizenship of many Samoans especially).

The targeted migrant communities or populations consist of all households where at least one member from the household was born in either Tonga or Samoa. The 'Key Informant' sampling methodology was adopted [9], since there is no population base to draw from for any kind of random or stratified sampling. Since the sampled migrant households could not be selected on a purely random basis neither the probability of the sampling error nor reliable confidence intervals could be calculated. To ensure that the survey obtained a representative proportion of socio-economic migrants, the Statistical Local Authorities (SLAs) from which the sample was drawn were classified into socio-economic strata. The distribution of migrant households across the SLAs was assumed to reflect the composition of the migrant population in terms of the relative socio-economic situation of its members. Church and other community representatives were approached and the purpose of the exercise explained and discussed, before the actual interviewing began. This ensured not only the cooperation of the interviewees as well as identifying, locating and interviewing the households that make up the population. It is believed that any resulting biases were largely off-set by the size of the sample.

The survey was conducted by interviewers from the migrant communities themselves. To minimise sample bias a number of other procedures were followed. With the Samoan community, a quota system was used to ensure that the numbers of respondents were apportioned across the different church congregations in accordance with their estimated relative sizes, thereby establishing a representative balance amongst all of the churches. With the Tongan community, where the chosen interviewers were community leaders who had access to confidential community lists from other sources, it was considered unnecessary to follow the same church-based quota system. When selecting households for inclusion in the sample the interviewers were unable to pre-select on the basis of the respondents' actual socio-economic situation. Interviewers were therefore assigned a quota of households to survey from each of the four strata, on the assumption that this would ensure a representative crosssection of income levels in the overall sample. Interviewers were instructed to apportion their samples across the SLAs on the basis of the proportions of migrants in each of the strata. As the final sampling was based largely on migrant households that were associated with the various ethnic community groups, churches and other organisations, it is conceivable that households from these higher socio-economic strata do not participate as actively in the community organisations. It is therefore possible that the Samoan sample is slightly biased towards households in the lower socio-economic groups and with stronger ties to the Samoan ethnic community.

The composition of the two sub-samples and the combined sample is given in Table 1. The total sample of Tongan and Samoan migrants living in Brisbane and Sydney was 1294; some 343 (26.5\% of the combined sample) were from Brisbane and 951 (73.5\% of the combined sample) from Sydney. Among the respondent households 153 , or $11.8 \%$ of the combined sample, can be defined as nurse households. As the survey was on a household basis, the surveyed nurses were either heads of household, the spouses of household heads, or, members of a household; all are hereafter referred to as 'nurse households', as distinct from 'others'. The households with nurses are not subsequently differentiated according to the nurse's status within the household. There were too few Samoan nurses for disaggregation by national groups. Previous work has however shown that Tongan migrants have a higher likelihood of remitting compared with Samoans, controlling for all other observable characteristics $[10,11]$. That almost $12 \%$ of the sample was nurse households is indicative of the significance of skilled health worker migration from the South Pacific to Australia.

\section{Sample characteristics}

Variable definitions and codes

Table 2 shows the sample means and standard deviations for a selection of socio-economic and demographic variables used in this study, and thus identifies some of the key characteristics of the sample. The names and definitions of the variables are as follows: Household income level, expressed in 1994 Australian dollars, after tax, as declared by the head of household for the 12 month period preceding the survey (INCOME); 
Table I: Composition of the sample

\begin{tabular}{|c|c|c|c|c|c|c|c|}
\hline \multirow[b]{2}{*}{ Tongans } & \multirow{3}{*}{$\begin{array}{l}\text { Nurses } \\
\text { Others }\end{array}$} & \multicolumn{2}{|c|}{ Brisbane } & \multicolumn{2}{|c|}{ Sydney } & \multicolumn{2}{|c|}{ Combined } \\
\hline & & 23 & $6.7 \%$ & 96 & $10.1 \%$ & 119 & $9.2 \%$ \\
\hline & & 154 & $44.9 \%$ & 513 & $53.9 \%$ & 667 & $51.5 \%$ \\
\hline \multirow[t]{3}{*}{ Samoans } & Nurses & 9 & $2.6 \%$ & 25 & $2.6 \%$ & 34 & $2.6 \%$ \\
\hline & Others & 157 & $45.8 \%$ & 317 & $33.3 \%$ & 474 & $36.6 \%$ \\
\hline & Total & 343 & $100.0 \%$ & 951 & $100.0 \%$ & 1294 & $100.0 \%$ \\
\hline \multirow[t]{2}{*}{ Both Groups } & Nurses & 32 & $9.3 \%$ & 121 & $12.7 \%$ & 153 & $11.8 \%$ \\
\hline & Others & 311 & $90.7 \%$ & 830 & $87.3 \%$ & 1141 & $88.2 \%$ \\
\hline
\end{tabular}

Table 2: Sample means and standard deviations

\begin{tabular}{|c|c|c|c|c|c|c|}
\hline & \multicolumn{2}{|c|}{ NURSES } & \multicolumn{2}{|c|}{ OTHERS } & \multicolumn{2}{|l|}{ COMBINED } \\
\hline & Mean & Std. Dev. & Mean & Std. Dev. & Mean & Std. Dev. \\
\hline TONGAN (\%) & 0.778 & 0.417 & 0.585 & 0.493 & 0.607 & 0.489 \\
\hline INCOME (A\$) & 37604.027 & 16115.675 & 29967.769 & $14 \mid 87.022$ & 30886.834 & 14638.300 \\
\hline REMITTER (\%) & 0.934 & 0.250 & 0.821 & 0.384 & 0.834 & 0.372 \\
\hline TOTREM (A\$) & 3196.026 & 3355.530 & 2585.374 & 3511.103 & 2657.076 & 3497.460 \\
\hline REMPROP (\%) & 0.095 & 0.126 & 0.095 & 0.110 & 0.095 & 0.125 \\
\hline LAND (\%) & 0.425 & 0.496 & 0.351 & 0.477 & 0.359 & 0.480 \\
\hline OWNAUS (\%) & 0.386 & 0.488 & 0.252 & 0.435 & 0.268 & 0.443 \\
\hline OWNOVS (\%) & 0.438 & 0.498 & 0.379 & 0.485 & 0.386 & 0.487 \\
\hline AGEHOH (Yrs) & 38.475 & 8.538 & 40.592 & 10.851 & 40.323 & 10.605 \\
\hline AGENURSE (Yrs) & 36.901 & 7.959 & N/A & N/A & N/A & $\mathrm{N} / \mathrm{A}$ \\
\hline SEXNURSE (\%) & 0.954 & 0.210 & $N / A$ & N/A & N/A & $\mathrm{N} / \mathrm{A}$ \\
\hline MARRIED (\%) & 0.869 & 0.338 & 0.878 & 0.327 & 0.877 & 0.328 \\
\hline PARENT (\%) & 0.608 & 0.490 & 0.608 & 0.488 & 0.608 & 0.488 \\
\hline NURSEHOH (\%) & 0.307 & 0.463 & $N / A$ & N/A & $N / A$ & $\mathrm{~N} / \mathrm{A}$ \\
\hline SPOUSE (\%) & 0.053 & 0.224 & 0.087 & 0.282 & 0.083 & 0.276 \\
\hline VISITOR (\%) & 0.333 & 0.473 & 0.262 & 0.440 & 0.270 & 0.444 \\
\hline HOUSNUM (\%) & 4.163 & 1.830 & 4.288 & 2.038 & 4.274 & 2.014 \\
\hline INTENT (\%) & 0.164 & 0.372 & 0.124 & 0.330 & 0.129 & 0.335 \\
\hline ABSENCE (Mnths) & 138.497 & 73.822 & 111.747 & 63.024 & 114.910 & 64.941 \\
\hline
\end{tabular}

(i) Whether the birthplace of the household head was in Tonga (as opposed to Samoa) (TONGAN);

(ii) Whether the household remitted to their country of origin during the 12 month period preceding the survey, 1 if yes otherwise 0 (REMITTER);

(iii) Household remittances in all forms, expressed in 1994 Australian dollars as declared by the head of household for the 12 month period preceding the survey (TOTREM);

(iv) Household remittances as a percentage of household income, expressed as a percentage (REMPROP);

(v) whether the head of household owned land in his or her country of origin, 1 if yes otherwise 0 (LAND); (vi) whether the head of household owned non-land assets in his or her country of origin, 1 if yes otherwise 0 (OWNOVS);

(vii) whether the head of household owned assets to the value of at least \$A5000 in Australia, 1 if yes otherwise 0 (OWNAUS);

(viii) Age of household head in years (AGEHOH);

(ix) Age of nurse in years (NURSEAGE);

(x) Gender of nurse (SEXNURSE);

(xi) whether the head of household is married, 1 if yes otherwise 0 (MARRIED) 
(xii) whether the head of household and/or spouse still have at least one living parent in country of origin, 1 if yes otherwise 0 (PARENT);

(xiii) Whether the nurse is the stated household head (NURSEHOH);

(xiv) whether the head of household is married with spouse still in the home country, 1 if yes otherwise 0 (SPOUSE);

(xv) whether the household had received house-guests to stay during the preceding 12 months, 1 if yes otherwise 0 (VISITOR);

(xvi) The number of persons living in the household (HOUSNUM).

(xvii) whether the head of household intended to return to his or her country of origin, 1 if yes otherwise 0 (INTENT);

(xviii) the number of months since the migrant first emigrated (ABSENCE);

\section{Demographic characteristics}

The nurse was the stated household head in $30.7 \%$ of the nurse households. The average nurse household size was 4.2 persons, very similar to the mean size of other households of 4.3. The average age of the nurses was 36.9 years, in comparison with 40.6 years for other respondents; $95.4 \%$ were women and $86.9 \%$ were married. (Some $5.5 \%$ were married but not living in the same country as their spouse, who was therefore outside Australia, in comparison with $8.7 \%$ for other households.) On average, nurse households had spent 11.5 years living abroad, compared with 9.3 years for others. A higher proportion of nurse households (16.4\%) stated that it was their intention to return home, in comparison with others $(12.4 \%)$.

Income and assets

Nurse households enjoyed significantly higher mean incomes than other households, $\mathrm{A} \$ 37,604$ compared with $A \$ 29,968$. A higher proportion held significant assets in Australia, 38.6\% compared with 25.2\%, and a higher proportion also held significant assets in their country of birth, $43.8 \%$ compared with $37.9 \%$. A higher proportion of nurse households owned land in their country of birth: $42.5 \%$ compared with $35.1 \%$. In terms of family ties to the country of birth, a significantly higher proportion of nurse households had hosted visitors from home in the last year, $33.3 \%$ compared with $26.2 \%$ of all households. The identical proportion of nurse and other households $(60.8 \%)$ had at least one living parent or parent-in-law still living in their country of birth.

That nurse households earned significantly higher incomes than other migrant households could reflect the occupational status of their spouses. However, as the data in Table 3 show, this is clearly not the case for either nurse heads of household $(\mathrm{HOH})$ or non-heads.

Indeed, over $50 \%$ of nurses' spouses were unskilled labourers and only $8.4 \%$ of nurses' spouses had the equivalent status to that of a nurse (i.e. managerial/professional category). There is therefore good reason to assume that income and remittance levels of nurse households reflect the income levels of nurses rather than that of their spouses.

\section{Determinants of remittances \\ Definition}

Remittances can take different forms, some of which are not accounted for in the official balance of payments remittance estimates in either the sending or receiving country. Remittances are defined here as including the following forms of international resource transfer by the migrant household to households or other individuals and organisations overseas:

(i) money transfers sent via the formal banking system to households;

(ii) money transferred informally in cash (bills) or via an informal agent to households;

(iii) the value (in Australia) of all goods sent to households;

Table 3: Occupational status of nurses' spouses

\begin{tabular}{|c|c|c|c|c|c|c|c|c|}
\hline$(n=1156)$ & Manag/ Prof & Admin/ Cleric & Skilled Labour & Labour & Hsewk & Unspec & Unemp/Retired & Student \\
\hline Nurse non-HOH $(n=100)$ & $8.0 \%$ & $9.0 \%$ & $25.0 \%$ & $52.0 \%$ & $0.0 \%$ & $0.0 \%$ & $4.0 \%$ & $2.0 \%$ \\
\hline Nurse HOH $(n=19)$ & $10.5 \%$ & $21.1 \%$ & $0.0 \%$ & $47.4 \%$ & $10.5 \%$ & $0.0 \%$ & $10.5 \%$ & $0.0 \%$ \\
\hline All Nurses $(n=119)$ & $8.4 \%$ & $10.9 \%$ & $21.0 \%$ & $51.3 \%$ & $1.7 \%$ & $0.0 \%$ & $5.0 \%$ & $1.7 \%$ \\
\hline Other HOH (n = I I 37) & $7.1 \%$ & $12.7 \%$ & $15.9 \%$ & $34.1 \%$ & $2.3 \%$ & $4.8 \%$ & $20.8 \%$ & $2.2 \%$ \\
\hline
\end{tabular}

Table notes: $\mathrm{HOH}$ indicates respondent self-declared head of household. For nurse households the total sample is less than $153(\mathrm{n}=119)$, as not all nurses were married or living with their spouse in Australia. Where the nurse is living with a parent, the occupational status of the parent head of household is reported in this table. 
(iv) payments made by the migrant on behalf of households;

(v) donations by the migrant to other institutions or organisations; and,

(vi) deposits made into bank accounts held by the migrant overseas.

Migrant transfers in-kind, mainly in the form of goods are usually sent to households as "gifts" or "personal effects", are often not recorded as imports and escape any duties. A significant amount of these end-up in informal sector fleamarkets [12]. Most such transfers would therefore be unrecorded, either as remittances or as imports, in the balance of payments statistics. Migrants also remit to other institutions and organisations, mainly churches [13-15]. Donations are often collected by the churches in the host countries and are held in bank accounts there, to be transferred overseas or used to settle international payments on behalf of the church in the country of origin. If these transactions show up at all in the balance of payments records, they will not appear as migrants remittances.

Migrants sometimes also make payments on behalf of relatives or others in their country of origin. These consist of payments for services such as insurance premiums paid to Australian or New Zealand-based companies, schooling and other educational expenses or, most commonly, payments for international airfares made directly to the airlines. In most instances these airfares enabled relatives to visit the migrants in their host countries. This usually also implies that all other travel costs and living expenses are born by the migrant. These too should be treated as effective "remittances" to the country of origin as they amount to foreign exchange transfers from the migrants to overseas residents for international travel. Such payments would appear neither as current account receipts nor as payments for overseas travel.

Finally, migrants also transfer money to their country of origin for the purpose of acquiring assets there on their own behalf $[16,17]$. These could be financial savings deposits with banks, or other physical assets such as land, housing, farm equipment and supplies, inventories for small businesses, and so on. These transfers can be made directly and via the formal network, but are often undertaken indirectly via a third party or agent on an informal basis. The questionnaire was designed to capture all these diverse forms of remittances.

\section{Determinants}

A range of characteristics can be expected to affect a migrant's remittance behaviour. Unfortunately, as Lucas and Stark noted almost two decades ago, it largely remains true that 'there is surprisingly little statistical evidence on the motives for remitting, and the few studies that have appeared are not couched in terms of testable hypotheses derived from a theoretical framework.' [18]. It is therefore necessary to rely on a limited amount of empirical and theoretical work to identify possible variables for inclusion in a more formal, multivariate regression model.

Two closely related motivational characteristics that stand out in other studies of Pacific island migrants are the strength of the migrant's ties to the home versus host community, and the migrant's intentions to return. Variables related to these which other studies have found to be significant include, (a) whether permanent residence had been gained (which, it could be argued, influences the probability of return migration); and, (b) whether former dependents had joined the migrants living overseas $[19,20]$. Brown $[10,11]$ found that the presence of a surviving parent or spouse in the home country increased the migrant's propensity to remit, while the larger the number of dependents of the migrant living in Australia, the less likely the migrant was to be remitting. Where both determining factors had occurred, remittances were virtually non-existent [21]. Generally, as in the case of Fijians in Sydney [22], the level and regularity of remittances was found to be a positive function of intent to return. This is also well documented in the case of Tongans and Cook Islanders overseas [23].

Consequently migration decisions are shaped within a family context. Migrants leave to meet certain family expectations, one of which is the supply of remittances. A previous study showed that almost two-thirds of nurse migrants indicated that the opportunity to earn a higher income was a major reason for migration [24]. There is an expectation that migration will benefit extended households and even villages. Though greater ease of migration and a growing familiarity with external affairs have been amongst the factors contributing to an increase in individual, rather than family or lineage, decision-making, these expectations remain valid. Overall migration is directed at improving both the living standards of those who remain at home and the lifestyle and income of the migrants. More specifically, in rural areas and home islands, as in Tonga, 'migration and remittances... are perceived solely as means for improving family incomes and welfare rather than for direct or indirect national economic development' [19]. Migration has rarely been an individual decision to meet individual goals, nor has it been dictated by national interests.

The underlying economic rationale of migration is reflected in the household organisation of migration. Families in many respects operate on a world stage, so that the 'international scale of family operations, still tied to 
kin at home...would equal or exceed in value the Tongan national product' [25]. Extending from this notion Bertram has suggested that Tongan (and other similar) households are characterised 'by remittance transfers among various component parts of the 'transnational corporations of kin' which direct the allocation of each island's family labour around the regional economy' [26]. Similarly Tongan 'families deliberate carefully about which members would be most likely to do well overseas and be reliable in sending remittances' $[27,28]$ although there is, seemingly paradoxically, an accompanying shift towards individualism [29]. While all such statements have been made in the most general sense, and often on the basis of small undifferentiated samples, there is no reason to suppose that they do not apply to skilled workers, and hence to nurses. Indeed the evidence of the present analysis suggests that they almost certainly do apply to nurses.

As family ties are important determinants of remittances, it is sometimes mistakenly believed that migrants are unlikely to remit for purposes other than altruism, where altruism is perceived as transfers for purposes of family consumption support. However, others have suggested that migrants' remittances are motivated by additional factors that could offset any weakening of such altruistic motives. Stark [30,31] and Lucas and Stark [18], for instance, have argued that migration decisions are best understood as part of the family's risk reduction or 'family co-insurance arrangement' which they liken to the portfolio-investment strategy of a firm and in which there is an intertemporal contractual agreement between the migrant and 'home' [32,33]. They argue that remittances are often a repayment of the expenditure by family on the migrant's education and are thus directly related to the migrant's educational level. Households may even consciously persuade and sponsor various members to migrate as insurance in times of hardship, and in anticipation of eventual repayment. Poirine [34] and Brown and Poirine [35] take this argument a step further, arguing that remittances often constitute part of an informal loan agreement between the migrant and non-migrant family members, through which the investment in the migrant's human capital is financed (the loan) and later repaid by the working migrant (the remittances). After the loan is repaid the migrant sometimes becomes a source of loan finance for investment in the education of the next generation of non-migrants, implying no tendency for remittances to decay.

Self-interest can also play a part in the migrants' decisionmaking framework, either in terms of inheritance-seeking behaviour or as a rational investment. From studies of migrants in Botswana, India and the Philippines, Stark $[30,31]$ found evidence of remittances which were moti- vated by 'tempered altruism or enlightened self-interest'. He suggested that 'considerations such as an aspiration to inherit, maintenance of rural investments, and the intentions to return mean that the migrant retains a vested interest in his original home beyond altruism' [31]. An inheritance seeker will continue to remit in order to stay in favour with family.

Migration and remittances also sometimes motivated by 'target saving', where migrants retain much of their savings with them in the host country, only remitting their accumulated savings on, or over a period of time shortly before, their final return $[33,37]$. In such cases the remittance profile would be positively sloped over the latter part of the migrant's stay. Thus for overseas Pakistanis, where the probability of returning was extremely high, remittance levels did not decline [38]. Especially where a migrant is intending to return home to retire, remittances of accumulated savings would not necessarily take the form of one lump-sum transfer at the end of the migrant's period of absence, but still be concentrated over a number of years prior to the migrant's retirement. Stark [30] and Macpherson [39] have suggested that, in this case, migrants will transfer savings into long-term assets such as land, housing or livestock, and possibly other community or "social" assets with a view to enhancing their prestige or political influence in the 'home' community. Remittance behaviour that is motivated by this form of investment may continue independently of altruistic family consumption support.

In other contexts migrants sometimes evolve into small entrepreneurs. Studies in the Caribbean Basin countries found strong links between remittances and small business development in the remittance-receiving countries, that were indicative of at least some investment-motivated behaviour [40] In at least one Punjabi village there has been an evolution of remittance use beyond altruistic family support into a 'business investment stage' [41]. For both Samoa and Tonga migrants are motivated to remit for reasons of saving and investment [15]. Remittances in kind and the practice of selling remitted goods as part of an informal international business operation are also an important aspect of remittances by Tongan migrants [12]. Such behaviour emphasises the economic role of the Pacific transnational corporation of kin. In another study, using an econometric analysis of secondary data on savings and real interest rate differentials, Tongan and Samoan migrants' remittances were responsive to financial incentives in the remittance-receiving countries [42]. This suggests that remittances serve as a source of loanable funds and are potentially responsive to changes in interest rate differentials. 
Gender plays an important role in remittances. Virtually without exception, where there are data, women tend to be more frequent remitters, although they may lack the earnings capacity to send the same amount as men. In a number of places, including Samoa, women are specifically referred to as the most reliable remitters [43]. Amongst Auckland Tongans non-remitters were much more likely to be males; although the average sum sent by men was higher than that of women, the latter sent 15\% of their net income, compared with men, who sent $11 \%$ [44]. The same kind of situation occurs in other Polynesian contexts and has been attributed to Polynesian social structures, with women having greater responsibility for the maintenance of the household. Women are argued to have a much better understanding of household needs throughout the Pacific [22] and are more likely to respond to those perceived needs. It might therefore be expected that nurses, who are predominantly female, will be more reliable senders of remittances.

There is also some evidence from another study of Pacific island nurses that would suggest that nurses are more likely to be altruistically inclined than others. A survey of Tongan and Samoan nurses within the Pacific [24] demonstrated that nurses displayed a higher level of altruism, in terms of why they entered the profession. Out of a sample of 34 Samoan nurses some 23 stated that they enjoyed being able to help people and 17 valued the opportunity to competently care for their families. Indeed, family was the main reason for nurses entering the profession, with 29 having entered in order to care for members of their family. From a similar sample of 30 nurses in Tonga, some 28 had entered the profession primarily to care for their families. In both Tonga and Samoa income was not a primary consideration for choice of occupation. While these samples are obviously different from the migrant nurses discussed here, it is unlikely that migrant nurses are less altruistically inclined.

Irrespective of what motivates remittances, the propensity to remit and the level are influenced by the capacity of migrants to save. This depends largely on the migrant's income and net wealth situation, taking into account the number of dependents in the migrant household. In the empirical sections that follow an attempt is made to analyse Tongan and Samoan migrants' remittances in terms of a number of characteristics identified here as most likely to affect their motivation and capacity to remit.

\section{Remittances over time}

There has always been concern that remittances decline over time, in total and from particular households and individuals, due to lower migration rates, recession and a decrease in migrants' willingness to remit $[44,46][47,48][29,59]$. An important issue in the present context is whether per capita remittance levels will decline as the nurses' length of absence increases and ties to their countries of origin weaken. Furthermore it has been suggested that, even with continued migration, the anticipated decline in remittance rates is likely to occur due to family reunification and greater integration of the migrants in the host communities. This process, it is argued, reduces migrants' ability and willingness to remit: ability because of the increased number of dependents now living in the migrants' households, and willingness because of fewer kinship ties at home. Since migration by Pacific islanders is generally long-term, it would then follow that the aggregate level of remittances will also decline over time, unless the rate of new migration is sufficient to offset declining average remittance levels among the stock of "older" migrants.

A belief in remittance decay at the level of the individual migrant is perhaps to be expected. The longer the migrant is away, social ties and distant perceptions of needs and wants are likely to decline. Successful migrants may be followed by others from the same family with perhaps greater commitment. Initial savings targets (where they existed) may have been met and investment in the host, rather than source, country seem to be more rational as the probability of return declines. Although migrants face a life cycle of obligations to their home areas, these obligations are likely to lose their immediacy, to compete with new obligations and to be increasingly ignored. Samoan migrants who are seemingly permanent residents overseas are under less pressure to remit as their village commitments become less intense and less significant [43] and they acquire financial commitments in their host country. On the other hand it has been suggested that the peculiarities of the 'complex inter-relationships and social obligation patterns of the islanders' could imply a continuation of remittances by permanent migrants over the longer term, albeit at possibly lower levels [50].

Advocates of the remittance decay hypothesis in the Pacific draw support for their arguments mainly from studies of migrants in other countries. Thus Forsyth's [3] study postulated a remittance decay function for the South Pacific based largely on evidence from an OECD study of remittance behaviour in Europe [51]. The longer the duration of the migrants' stay abroad, and the greater the associated decline in the number of dependents at 'home', the weaker migrants' motivations to remit are assumed to become, hence sustained high rates of remittance tend to be characteristic of migrants who intend staying in the host [country] for a relatively brief period and then returning home.... But such rates are unlikely to be sustained if the period of residence is extended ... [which] suggests a profile over time ... with remittances 
reaching a peak soon after arrival in the host country then gradually declining [3].

However other studies have found little evidence of remittance decay. Standing [52] cited three studies of Indian migrants which revealed that the level of their remittances did not decline with time, but rather plateaued at a positive and constant level.

Until recently there as been only limited data on which to conduct further investigation, beyond simple extrapolations based on unreliable, secondary time series data and other evidence of a more anecdotal nature. Remarkably little is known about Pacific island migrant communities in Australia and elsewhere, in terms of demography, education and occupation levels, socio-economic status, and their remittance behaviour and its correlates. Since remittances can take many forms, including informal transfers in cash or in-kind, and can pass through many different channels and networks, there are clear obstacles to making definitive assessments of remittance behaviour. This is not to deny the importance of other work that has been attempted in recent years. Unfortunately, the available data remain fragmentary and often inadequate for statistical analysis. Most existing studies were undertaken on small sample surveys among particular pockets of Pacific island migrants, where the sample size was constrained by limited budgets. Consequently, previous studies have failed to produce data sets large enough for rigorous statistical analysis. Nonetheless Vete [21] found that for Tongans in New Zealand there was a correlation between the number of dependents in Tonga and the amount of remittances. Broadly the same pattern was found amongst Tongans in Sydney. The level of remittances increased during the first few years of migration, up to around seven years, but then began to decline, although migrants who had been in Australia for more than 18 years still sent remittances [19]. On the other hand, Loomis found little evidence of remittance decay among Cook Islanders in New Zealand [23]. All of these studies were both based on small samples which cannot be considered statistically reliable, and relied on cross-tabulations which did not isolate the effects of other variables from the effect of the migrant's duration of absence.

From the same survey data that this present study uses, Brown subjected the remittance-decay hypothesis to rigorous empirical investigation $[10,11]$. Remittance decay was examined empirically at two levels. First, time profiles of average remittance levels and propensities were constructed from estimates for different cohorts of migrants, based on the number of years since first migrating. These descriptive statistics are presented here in tabular and graphical form. Second, a remittance function was estimated for each migrant community, using appropriate econometric techniques, and which attempts to separate the effect of time from all other influences on remittance behaviour.

These studies found little evidence to support the remittance decay hypothesis; that is the survey data did not indicate a significant decline in remittances the longer the time period that migrants spent away from home. This is important, as it indicates that there is no need for the numbers of new migrants to continually increase to maintain the same level of remittances to the island economies. It is therefore worth testing whether the same holds for nurse households. This is tested first, in the following results section, using descriptive data and plots of mean remittance levels against migrants' length of absence from home, and then using appropriate econometric methods.

\section{Results and discussion \\ Descriptive statistics}

Remittance levels are reported here using two different bases: a "Sample Average" and a "Remitters' Average". The former refers to the average for the entire sample, including those who did not remit at all during the previous financial year. The "Remitters' Average" is based on the total number of respondents who sent remittances in at least one of the above identified forms, thus it excludes those who did not remit in any form.

From Table 2 it can be seen that a significantly higher proportion of nurse households sent remittances home over the preceding months (93.4\% compared with $82.1 \%)$, and, on average remitted more, $A \$ 3,196$ compared with $\mathrm{A} \$ 2,585$ for other migrant households. (As the survey was undertaken in 1994, all Australian Dollar (A \$) values reported here are in terms of constant 1994 prices. In terms of 2003 prices, the comparable sums would be $\mathrm{A} \$ 3952$ (US\$2688) and $\mathrm{A} \$ 3197$ (US\$2174)). Using the mean level of remittances for nurse households (A $\$ 3,196$ in 1994 prices) and assuming this level is sustained for the mean number of years of absence for nurse households (11.5 years), the cumulative value of remittances would amount to $A \$ 36,750$ (in 1994 prices) per nurse household during their stay overseas (On an undiscounted basis, but also bearing in mind that these are constant 1994 values). This sum is likely to exceed the training cost of nurses within Tonga and Samoa. Given the shortage of nurses in Australia and New Zealand, and therefore the high demand for immigrant nurses, investment by Pacific island governments and families in nurse training constitutes a rational use of economic resources.

These data suggest that nurse households enjoy higher incomes, own more assets, and remit more than other migrants. However, it is also noteworthy that the mean value of nurse households' average propensity to remit 
Table 4: Remittances by years of absence

\begin{tabular}{|c|c|c|c|c|c|c|}
\hline COHORT & $0-5$ years & $5-10$ years & $10-15$ years & $15-20$ years & $20-25$ years & $>25$ years \\
\hline Nurses (n=) (\% total group) & $7(0.046)$ & $31(0.203)$ & $52(0.340)$ & $26(0.170)$ & $22(0.144)$ & $15(0.098)$ \\
\hline Others $(n=)$ (\% total group) & $62(0.182)$ & $78(0.229)$ & $32(0.094)$ & $36(0.106)$ & $50(0.147)$ & $83(0.243)$ \\
\hline \multicolumn{7}{|l|}{ Remitting households (\%) } \\
\hline Nurses & 0.857 & 0.967 & 0.981 & 0.885 & 0.905 & 0.867 \\
\hline Others & 0.823 & 0.833 & 0.846 & 0.813 & 0.725 & 0.904 \\
\hline \multicolumn{7}{|l|}{ Remittances/remitter (A\$) } \\
\hline Nurses & 3416.7 & 3713.8 & 3521.6 & 3378.3 & 3068.4 & 2984.6 \\
\hline Others & 1729.4 & 2996.5 & 3321.4 & 3263.1 & 3765.7 & 2656.0 \\
\hline \multicolumn{7}{|l|}{ Remittances/household (A\$) } \\
\hline Nurses & 2928.6 & 3590.0 & 3453.9 & 2988.5 & 2776.2 & 2586.7 \\
\hline Others & 1422.6 & 2497.1 & 2811.2 & 2652.2 & 2729.5 & 2400.0 \\
\hline \multicolumn{7}{|l|}{ Household Income(A\$) } \\
\hline Nurses & 29728.6 & 33953.3 & 36586.5 & 40087.5 & $4 \mid 257.1$ & 43020.0 \\
\hline Others & 22465.0 & 27537.4 & 31427.5 & $306 \mid 3.3$ & 32171.2 & 32280.8 \\
\hline
\end{tabular}

(remittances as a percentage of household income) is the same as other households (9.5\%). That is, despite earning larger incomes, nurse households remit the same proportion of those incomes.

Table 4 disaggregates the sample into six cohorts; 0 to 5 years; 5 to 10 years; 10 to 15 years; 15 to 20 years; 20 to 25 years; and 25 years or more, and is then split into nurse and other households.

For each cohort and category the following variables are shown: percentage who remitted; mean remittances per remitting household; mean remittances per migrant household; household income. These data are then shown plotted in Figures 1 and 2, where Figure 1 shows the time profile of remitting households and remittance levels while Figure 2 shows the time profile of income, remittance levels, and average propensities to remit.

It is clear from the first chart in Figure 1 that for all cohorts, except those who had been in Australia for more than 25 years, a higher proportion of nurse households than non-nurse households remitted. However, the graph suggests that the proportion of remitting nurse households declines slightly with length of absence, and converges with others who had been away for 25 or more years. The second chart in Figure 1 suggests that among the remitting households, nurse households are more generous remitters than others, especially among the younger cohorts. Again there is a convergence of remittance levels once the migrant has been away 20 or more years. The combined effects are shown in the third chart of Figure 1 where the profiles of remittance levels per migrant household are plotted. This chart shows more clearly a tendency for nurse household remittances to converge with other households after a 20 -year absence.
The charts in Figure 2 suggest that the higher remittance levels of nurse households possibly reflect the higher mean income levels of nurse households for all cohorts (see the first chart in Figure 2). Indeed, when plotted in relation to remittance levels (second chart in Figure 2) it can be seen that in terms of the proportion of income remitted, it would be incorrect to conclude that nurse households are more generous than others (third chart in Figure 2). There is a steep decline in remittance propensity after a 10 -year absence. While nurses who have been away for 15 years or less have a higher average propensity to remit, the opposite is true for those who have been away for longer than 15 years. Nurse households' average propensity to remit falls to $6 \%$ for the 25 -years and- more cohort, compared with $7.5 \%$ for other households.

These findings suggest that while remittance levels appear to be higher among nurse households, and do not decrease significantly with length of absence from home, when their relatively higher income levels are taken into account, nurse households' propensity to remit declines faster than other households with length of absence, falling below other households after a 15-year length of absence. However, these tentative findings should be treated with caution as they are based on a comparison of sample means and, as with all univariate analyses, it is not possible to control for the effects of variables other than the migrants' occupation on remittance behaviour.

As previously argued it is necessary to isolate three different effects: the size effect, the composition effect, and the time effect [11]. It is possible that the remittance levels of the different time cohorts are influenced by compositional effects. In other words, it cannot be assumed that the compositional structure of each cohort is the same. Differences in average remittance levels between time cohorts 


\section{Remitting Migrant Households (\%)}

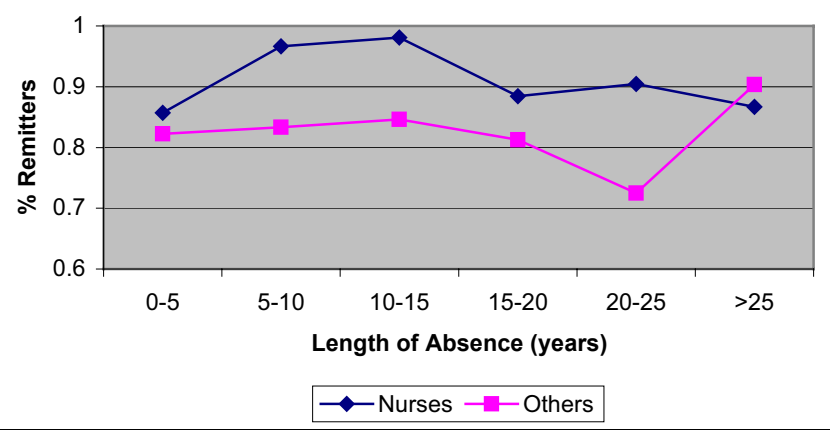

Remittances/Remitting Migrant Household (A\$)

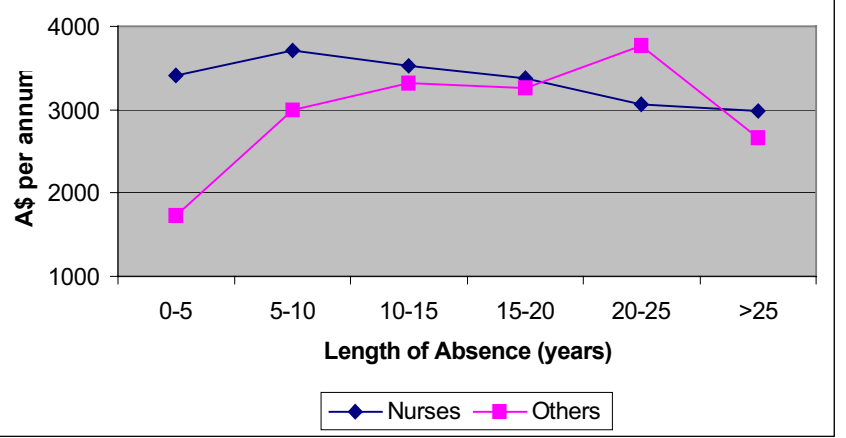

Figure I

Remitting migrants and remittance levels by length of absence

cannot necessarily be attributable to differences in the average length of absence between the cohorts. Indeed, the volatility of the plotted remittance functions in Figures 1 and 2 suggests that factors other than length of absence could be important determinants of remittances. To identify the most important compositional characteristics, and then assess the significance of length of absence while controlling for all other potential determinants of remittances, a multivariate regression analysis was undertaken.

\section{Multivariate analysis}

From the earlier discussion of remittance decay and the literature on the motivations and determinants of remittances, three broad categories of factors affecting a migrant's remittance behaviour can be distinguished, apart from the affect of duration of absence alone. First, there are factors that influence the strength of the demand-side pressures on a migrant from the receiving end, particularly family and community ties. Second, there are the supply-side factors that affect the migrant's capacity to remit, such as income and wealth. Third, there are the various behavioural characteristics that influence the migrant's motivations to remit, such as altruism or self-interest.

Two demand side variables are included in the model:

(i) whether the head of household and spouse still have at least one living parent in country of origin (PARENT);

(ii) whether the household had received house-guests to stay during the preceding 12 months which is an indicator of continued family or community ties (VISITOR).

Four supply-side variables are included in the model:

(i) Household income level, expressed in 1994 Australian dollars, after tax, as declared by the head of household for the 12 month period preceding the survey (INCOME);

(ii) To allow for a non-linear (quadratic) specification of the income relationship income squared is also included (INC2);

(iii) Whether the migrant held significant assets in Australia (OWNAUS);

(iv) The number of persons living in the household (HOUSNUM).

Four behavioural or motivational variables are included in the model:

(i) whether the head of household intended to return to his or her country of origin which if significant and positive indicates that those planning to return one day remit more than those who don't (INTENT);

(ii) whether the head of household owned land in his or her country of origin, which would be significant and positive if the migrant's remittances are motivated by continued maintenance of land assets at home (LAND);

(iii) whether the head of household owned non-land assets in his or her country of origin, which would be significant and positive if the migrant's remittances are motivated by business investment (OWNOVS);

(iv) to capture any unobserved differences in motivations to remit between Tongans and Samoans a dummy variable distinguishing Tongan households is included (TONGAN).

\section{Length of absence}

The length of absence of the migrant from home is covered by three variables: 
Mean Income/Migrant Household (A\$)

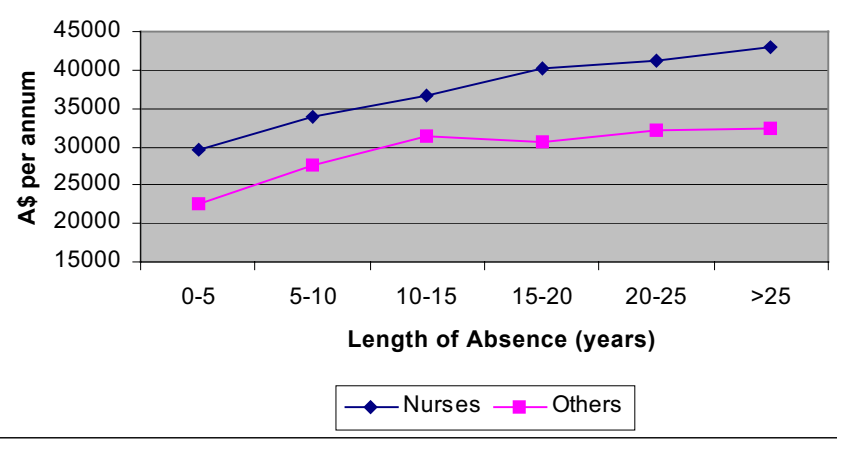

Remittances/Migrant Household (A\$)

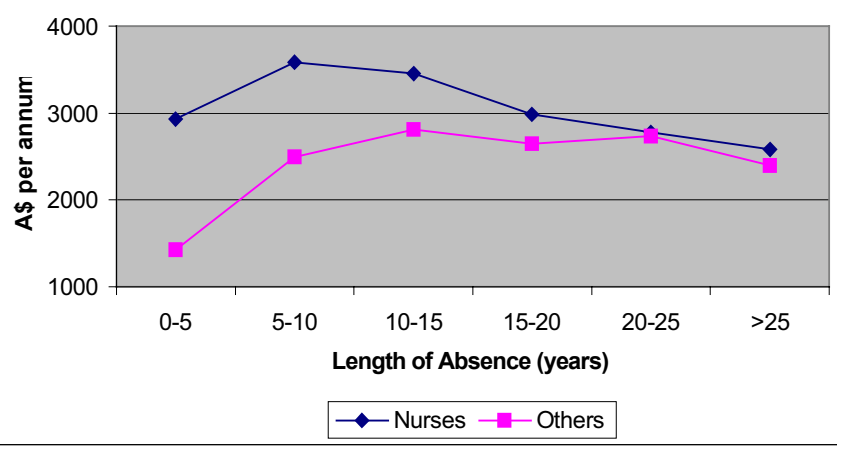

Average Propensity to Remit

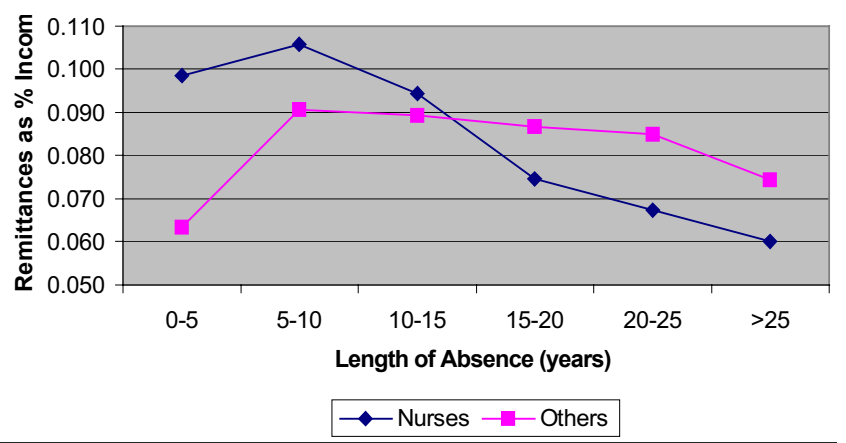

Figure 2

Income levels and remittance propensities by length of absence

(i) the number of months since the migrant first emigrated, which if significant and negative would indicate underlying remittance decay (TIME);

(ii) to allow for a non-linear (quadratic) relationship TIME squared is included (TIME2) (iii) as the variable PARENT is likely to capture some of the effects of time away, with the likelihood of a surviving parent decreasing with the passage of time, an interaction variable with PARENT and TIME was also included (PARTIME)

A generalized Tobit model using a Heckman two-stage sample selection method was used to estimate remittances, as the dependent variable (REMITTANCES) is a mixture of discrete (zero remittances) and continuous (positive remittances) parts and is therefore censored at zero. The main purpose of the generalized Tobit regression analysis used here is: (i) to identify which of the variables are most significant determinants of remittance behaviour, where remittance behaviour consists of two elements; whether or not to remit, and, if so, how much to remit; and, (ii) to measure the effect on remittance levels, in monetary terms, of changes in the most significant migrant characteristics. The dependent variable in the regression model is the value of remittances in 1994 Australian dollars over the 12 -month period preceding the survey.

The model and the regression results from the earlier analysis for the whole sample are reported in detail in Brown $[10,11]$. In these studies it was found that migrants with higher income, a parent or spouse at home, or who hosted a visitor from home during the year, remitted more, confirming that remittance behaviour is affected by both supply and demand-side variables. It was also found that migrants who intend to return remit more than those who do not. On the demand side it is evident that remittances are positively related to the existence of a surviving parent or spouse in the migrant's home country, and to the variable VISITOR which is a proxy for the strength of ties to the home community. No evidence was found of remittance decay (the time away from home variables were not significant).

As the purpose of this model is to compare the behaviour of one sub-group, nurses, with the rest of the sample, each variable was interacted with the variable NURSE to gauge the significance and extent of any differences between nurses and others in relation to remittance behaviour (i.e. NINCOME, NTIM, NTONGA, etc). The results of the regression model are reported in Table 5.

To identify the model the variables INCOME and INC2 were excluded from the probit equation on the grounds that income is likely only to affect the household's level of remittances, not the decision whether or not to remit. Length of absence was not statistically significant in the probit model, with or without the quadratic term. It should also be noted that the variable INTENT was not interacted with NURSE as in the case of all other variables 
Table 5: Generalized Tobit regression results

\begin{tabular}{|c|c|c|c|c|}
\hline \multirow[b]{2}{*}{ Variable } & \multicolumn{2}{|c|}{ Binomial Probit Model (Dep. Var. = REMITTER) } & \multicolumn{2}{|c|}{ Sample Selection Model (Dep. Var = REMITTANCES) } \\
\hline & Coefficient & Std. Error & Coefficient & Std. Error \\
\hline Constant & -0.1137 & 0.1131 & 408.8452 & 1020.8262 \\
\hline INCOME & - & _- & $-0.0715^{* *}$ & 0.0225 \\
\hline INC2 & - & - & $0.0002^{* *}$ & $.0003 E-04$ \\
\hline NINCOME & - & - & $0.0986 * *$ & 0.0356 \\
\hline NINC2 & - & - & $-0.0000 * *$ & $0.0004 \mathrm{E}-03$ \\
\hline TIM & $-4.79 \mathrm{E}-04$ & $\overline{9} .14 \mathrm{E}-04$ & $20.1092 * *$ & 5.9610909 \\
\hline TIM2 & $2.99 \mathrm{E}-03$ & $2.76 \mathrm{E}-03$ & $-0.0733^{* *}$ & 0.0205 \\
\hline NTIM & 0.6696 & 0.11882962 & $-35.2967^{* *}$ & 12.89333 \\
\hline NTIM2 & -0.1695 & 0.4610 & $0.1040 * *$ & 0.0360 \\
\hline TONGA & $0.8366^{* *}$ & $9.87 \mathrm{E}-02$ & 469.7008 & 389.2360 \\
\hline NTONGA & 0.9230 & 0.4580 & 605.0697 & 802.4204 \\
\hline PARENT & $0.2556 * *$ & 0.1304 & $969.4765^{*}$ & 430.2114 \\
\hline NPARENT & $-0.1775^{*}$ & 0.4183 & 271.9248 & 596.5333 \\
\hline OWNAUS & $0.3318 * *$ & 0.1223 & $215.177 \mid$ & 280.3138 \\
\hline NOWNAUS & -0.81556 & 0.4290 & 65.47659 & 635.9042 \\
\hline OWNOVS & $0.6310^{*}$ & 0.1323 & $649.2868^{*}$ & 266.8714 \\
\hline NOWNOVS & 0.5725 & 0.5352 & $-455.77 \mid$ & 663.6212 \\
\hline VISITOR & $0.2108 * *$ & 0.1758 & $867.0324 * *$ & 328.8612 \\
\hline NVISITOR & -0.0005 & 0.0009 & 849.3219 & 609.4681 \\
\hline INTENT & $2.99 \mathrm{E}-03$ & 0.0028 & $1069.797^{* *}$ & 291.2985 \\
\hline LAMBDA & 0.6696 & 0.1188 & 408.8452 & 1020.8262 \\
\hline Log Likelihood & & -464.9833 & & -9564.9332 \\
\hline (LRS) & & $231.4650 * *$ & & \\
\hline Rsqr & & $0.3227+$ & & 0.1747 \\
\hline
\end{tabular}

** significant at I\% level; * significant at $5 \%$ level + Veall-Zimmerman pseudo R-squared

since there were too few observations to produce a meaningful result. It is therefore assumed that the variable INTENT affects nurse households in the same way as all other migrant households.

The results of the probit model indicate that the overall model is significant at the $1 \%$ level. Tongans have a higher probability of being a remitter. Other variables of significance are: PARENT, but where nurse households are significantly less likely to remit because of a surviving parent; ownership of assets in Australia (OWNAUS), with nurses not significantly different from the whole sample; ownership of assets in the migrant's country of birth (OWNOVS), but with nurse households significantly less likely to remit for this reason; having recently hosted a visitor from the home country, with nurses not significantly different from others.

The results of the least squares regression model of remittance levels shows a number of interesting and contrasting findings in relation to nurse households, as discussed below.
Household income and remittances

The quadratic form of the income function is highly significant for both the whole sample and the nurse household sub-sample. The signs of the coefficients need to be interpreted with caution. It would appear that the underlying relationship for the whole sample is negative, but with a positive coefficient on the quadratic term. For the nurse households the coefficients on the two income variables have the opposite signs. However, when both terms are used to calculate the marginal propensity to remit at different income levels, it is evident that the relationship for both the whole sample and for nurse households separately is effectively positive. A plot of the marginal propensities to remit is shown in Figure 3.

At low levels of income below the sample mean, nurses have a higher marginal propensity to remit than the whole sample. But as the income level increases the marginal propensity of nurses increases at a much lower rate which means that for income levels above the mean level nurse households have a much lower marginal propensity to remit. 


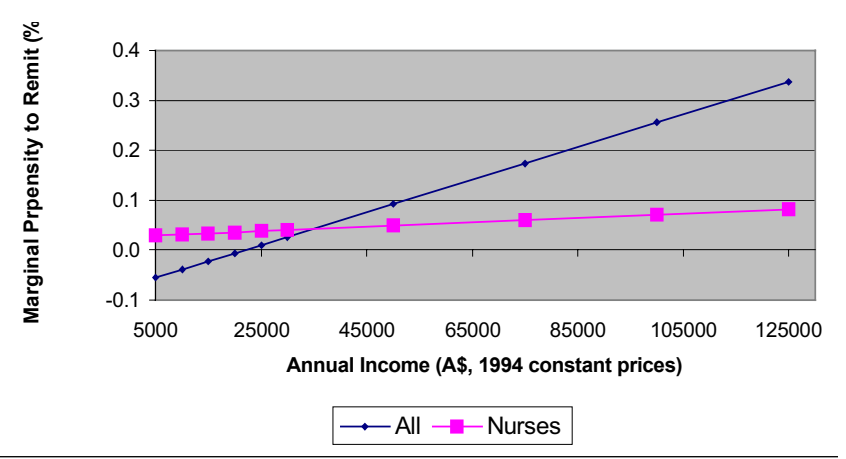

Figure 3

Marginal propensities to remit by income level (regression estimates)

This relationship is brought out more clearly in Figure 4 which compares remittance levels at different income levels, assuming a fixed length of absence of 10 years. It is evident from this chart that, other things being equal, nurse households at the lower end of the income scale remit a very similar proportion of income to the rest, but, as income levels increase and although their remittance levels increase, they become less generous than the rest in a relative sense, with an increasing differential as income increases. This however ignores the impact of other variables such as the migrant's length of absence from the home country.

\section{Length of absence and remittances}

The results of the model show that length of absence is a significant variable, and that length of absence has a significantly different effect on nurse households' remittances. The results indicate that there is a positive underlying relationship between remittances and time (which is counter-intuitive) with a negative coefficient on the quadratic term, suggesting a decay factor. With nurse households the coefficients are significant but with the opposite signs. This suggests that remittance decay is weaker for nurse households in comparison with the whole sample. Figure 5 shows the amount by which annual remittance changes with reference to changes in the length of time away, holding all other variables constant.

For the whole sample there is clearly a negative relationship. For a length of absence under 10 years, remittances increase with an extra year away but at a decreasing rate. Once the migrant has been away for 10 years, remittances fall and at an increasing rate with each extra year away. With nurse households the relationship is negative among the more recent cohorts, but at a decreasing rate. Once the

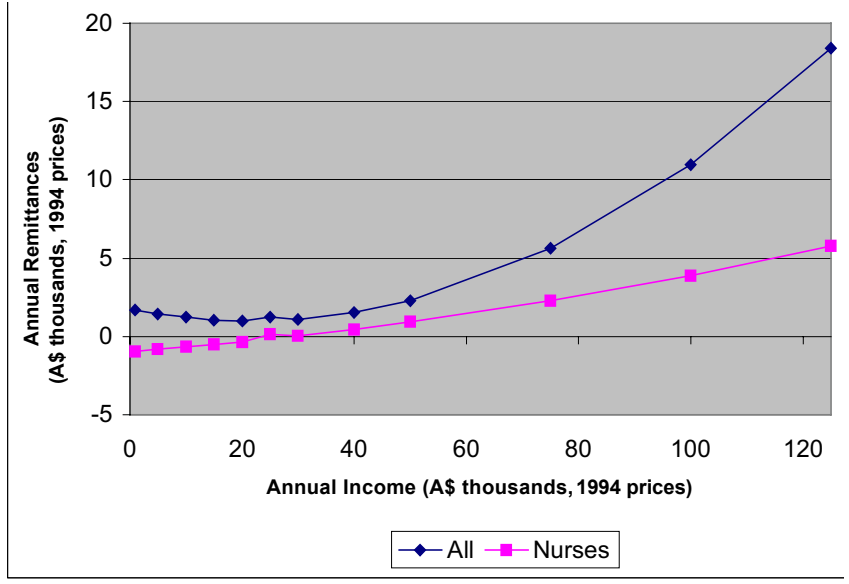

Figure 4

Remittances-to-income functions (regression estimates; length of absence $=10$ years)

migrant has been away for 20 years remittances begin increasing each year, so that by 40 years away they increase by almost $\mathrm{A} \$ 200$ per annum.

These relationships are shown clearly by the chart in Figure 6 where remittance levels are plotted against time away for a household at a level of income of $A \$ 30,000$ per annum.

It is clear that the remittance function for nurse households has a slight negative slope for the more recent cohorts, and then becomes positive for those who have been away for 20 years or more. For all groups together it is positive for households in the more recent cohorts but then decreases sharply after a 15 year absence, becoming highly negative.

\section{Other variables affecting remittances}

The results show that only a few other variables have a statistically significant impact on remittance levels. First, having at least one parent or in-law still living in the migrant's country of birth increases remittances by $\mathrm{A} \$ 970$ per annum. Second, ownership of assets in the migrant's home country has a positive impact on remittance levels. Those who own such assets remit an additional A \$649 per annum. Nurse households are not significantly different in terms of how this variable affects their remittance levels. Third, households that had recently hosted a visitor remitted A\$867 more per annum. Again, this relationship was not significantly different for nurse households. Fourth, where the household head intends to return home, the household remitted an additional A $\$ 1070$ per annum. Although the strengths of these relationships are 


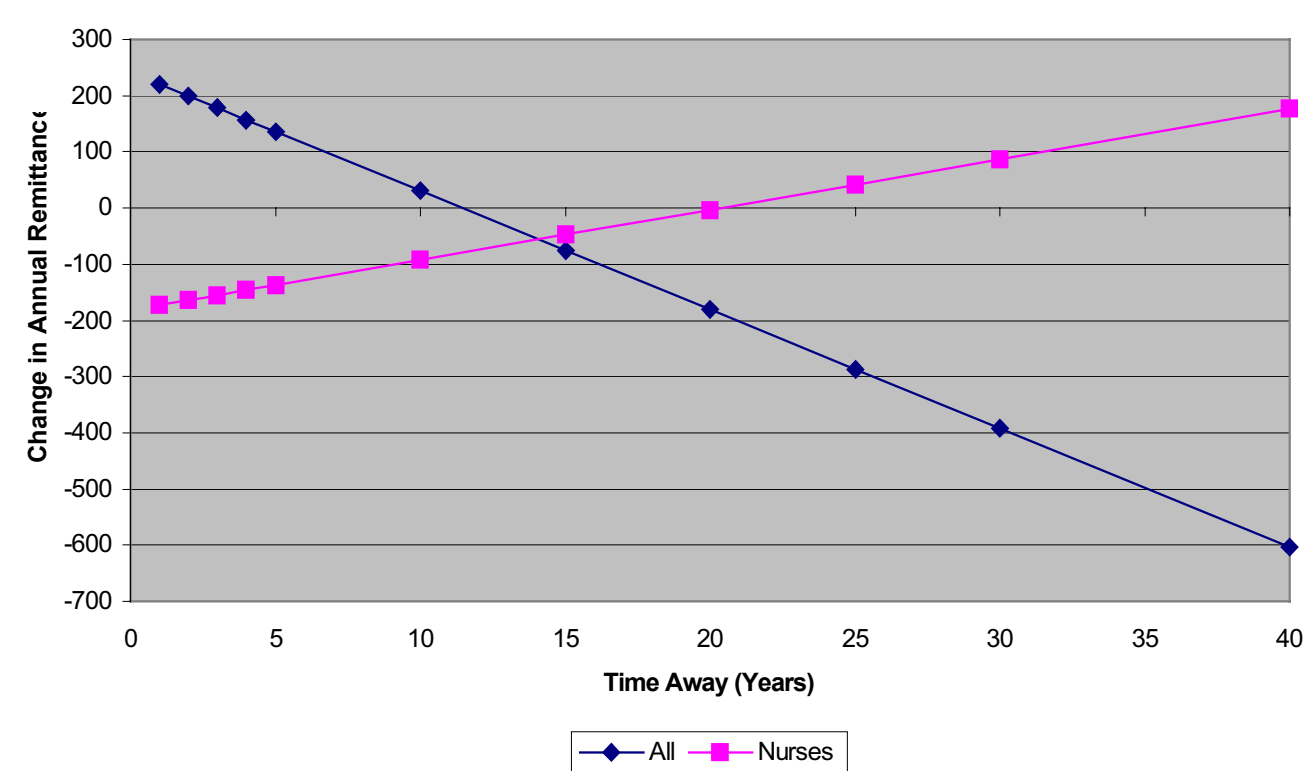

\section{Figure 5}

Change in remittance levels with duration of absence (regression estimates)

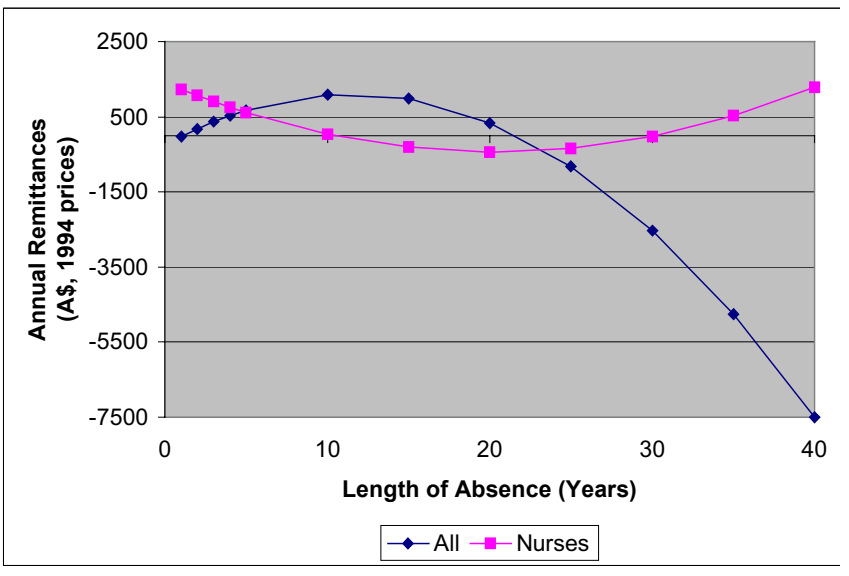

Figure 6

Remittance decay functions (regression estimates; income level $=A \$ 30,000$

not significantly different for nurse households, it is important to ascertain whether or not nurse households' remittances are more or less likely to be affected by these variables. From Table 2 it can be seen that in most instances a larger proportion of nurse households' remittances will be positively affected by these variables; some $43.8 \%$ of nurse households hold assets in their home country, in comparison with $37.9 \%$ for other migrants;
$33.3 \%$ had received visitors in comparison with $26.2 \%$ for other migrants; and $16.4 \%$ of nurse households intended returning, in comparison with $12.4 \%$ for other migrants. The same proportion of nurse households and other migrant households had a parent or in-law still living in the migrant's country of birth $(60.8 \%)$. Therefore, in addition to the influence on remittances of income level and duration of absence, the representative nurse household (i.e. where these other variables are set at their mean values) remits an additional $A \$ 1339$ per annum, in comparison with A $\$ 1196$ for other migrant households.

Table 6 also shows how these characteristics differ across the six cohorts. With the exception of the 'youngest' cohort, nurse households in every other cohort had a larger proportion of households with the key, remittance determining characteristics.

\section{The uses of remittances}

A large number of studies have documented the manner in which migrant remittances maintain social ties and act as insurance premiums for migrants, are principally used to repay debts, finance migration moves from kin and purchase consumer goods, including housing. However, it is necessary to denote that it is not strictly possible to identify the precise use of income from remittances as opposed to other sources, given the fungibility of cash income. In other words, remittances increase a household's income and thereby affect their consumption 
Table 6: Comparison of other significant variables by cohort (expressed as proportion of sub-sample)

\begin{tabular}{|c|c|c|c|c|c|c|}
\hline COHORT & $0-5$ years & $5-10$ years & $10-15$ years & $15-20$ years & 20-25 years & $>25$ years \\
\hline \multicolumn{7}{|c|}{ Parent in home country } \\
\hline Nurses & 0.429 & 0.742 & 0.712 & 0.538 & 0.455 & 0.400 \\
\hline Others & 0.710 & 0.680 & 0.657 & 0.602 & 0.427 & 0.105 \\
\hline \multicolumn{7}{|c|}{ Ownership of assets (\%) } \\
\hline Nurses & 0.000 & 0.419 & 0.423 & 0.500 & 0.591 & 0.400 \\
\hline Others & 0.484 & 0.356 & 0.416 & 0.369 & 0.360 & 0.301 \\
\hline \multicolumn{7}{|c|}{ Received visitor (\%) } \\
\hline Nurses & 0.000 & 0.323 & 0.404 & 0.269 & 0.364 & 0.333 \\
\hline Others & 0.194 & 0.219 & 0.226 & 0.322 & 0.347 & 0.277 \\
\hline \multicolumn{7}{|c|}{ Intent to return (\%) } \\
\hline Nurses & 0.000 & 0.161 & 0.154 & 0.154 & 0.190 & 0.267 \\
\hline Others & 0.367 & 0.091 & 0.107 & 0.129 & 0.084 & 0.188 \\
\hline
\end{tabular}

and saving behaviours. What needs to be addressed is the impact of this higher income on consumption and saving at the margin. As far as possible, this section attempts to address this issue in this way.

The use of additional income from remittances (hereafter referred to simply as remittances) often reinforces a traditional set of values and tends to reinforce the social hierarchy and hence strengthens traditional structures of social organisation. Remittances tend to go to senior family members, who use such money in familiar ways whilst, especially in the absence of younger family members overseas, structural changes (such as land tenure reform) tend to be discouraged. Overseas migrants usually retain land rights, even after long periods overseas, are unwilling to relinquish the security of these rights and may also discourage the expenditure of remittances in non-traditional ways. In Tonga migrants have been seen as part of a "transnational corporation of kin," that may seek to maximise extended household incomes across different continents. Remittances have raised living standards [54], contributed to employment (especially in the service and construction sectors) and eased balance of payments problems, despite contributing to inflation, especially in the larger Polynesian countries. However increased demand for improved consumer goods can usually only be met by further migration and it has generally been argued that little of the remittances has been invested in economic growth.

The majority of studies of remittance use in the Pacific suggest that, despite a considerable diversity in the use of remittances, their primary use has been for consumption objectives. In a World Bank report on Tonga, it was stated that: 'Large private remittances and official grant inflows have enhanced consumption and resulted in negative gross domestic savings equivalent to nearly a quarter of GDP.' [54]. Conventional wisdom suggests that remit- tances are overwhelmingly used for consumption objectives and limited amounts are directed towards investment. It is not surprising that remittances are primarily used for consumption, given the range of barriers to investment $[45,55]$ yet, in reality, there are a series of different and distinct uses of remittances [44].

First, remittances are used to pay debts and the fares of subsequent migrants, usually from the same household. Second, remittances are directed into the purchase of consumer goods. At the national level estimates for Tonga suggest that about $70 \%$ of remittances were spent on imported consumer goods, including tinned and preserved foods, beverages and tobacco [19]. Tongan householders themselves rarely perceive their use of remittances as unproductive or as examples of conspicuous consumption; indeed 'nothing is more productive than to be able to provide for their daily subsistence and to have the economic power to fulfil their family and social responsibilities' [56]. Increased and improved consumption is thus of some importance in Pacific island states.

The third use of remittances is in the construction or purchase of improved housing. Use of remittances for housing is so widespread in some areas, such as Tonga, that it is often stated that casual inspection of village housing enables conclusions to be quickly made on which households have migrants overseas. Overall expenditure on improved housing plays a diverse and variable role in its contribution to welfare, security, prestige and income-generation. Moreover, to a greater extent than other forms of expenditure, it generates a multiplier effect, especially through its contribution to employment and to the expansion of some other local industries and services.

Fourth, early studies of the use of remittances provided little evidence in the Pacific island states of remittances 
directly contributing to savings or other forms of financial investment [45]. Immediate objectives invariably seem to have been more significant. But, remittance receiving households in Tonga enjoyed a much higher savings rate than those that did not receive remittances [17]. There is also increasing evidence that money that might have been remitted is saved within the sending countries, and used by the savers at a later date. Moreover, as noted above, Foster [42] has demonstrated for both Tonga and Samoa, that remittances and savings are both linked to interest rates. Thus, despite the focus that much of the existing literature gives to the social context and impact of remittances, there are good indications that both senders and recipients of remittances behave in an economically rational manner.

Fifth, remittances are used for various forms of investment, sometimes in the agricultural sector but more frequently in the service sector, and especially into stores and transport businesses. Nevertheless there is a general belief that, as in Samoa, 'remittances were not used for capital investment or, to be more specific, for speculative capital investment' [43]. Remittance money has constituted the start-up money for many small shopkeepers. Walker and Brown [17] found that a significant proportion of remittances received by Tongan and Samoan households, including those of the nurses, was used for 'business and farm investment'. Apart from this, it is very difficult to find evidence of any significant investments emanating from remittances. Throughout Tonga the increased use of remittances for investment purposes, in fishing, agriculture, stores and transport businesses, attests to the shift from consumption to investment $[53,17]$. Where there are opportunities, and where consumption goals have been satisfied, remittances are therefore used for investment.

Sixth, a proportion of remittances are invariably used for community objectives, such as support for social organisations and institutions, usually churches. Both in Tonga and Samoa [43], substantial sums have been remitted directly or indirectly for church construction and maintenance, pastors' incomes and related activities. Some 18\% and $41 \%$ of Tongan and Samoan migrants' remittances respectively were sent to other, non-household institutions [16]. Such related activities include the high schools and primary schools run by the churches, thus illustrating the wider welfare gains from such remittances $[19,53]$. Remittances are also directed to health centres, local sporting associations, women's groups, specific local development projects, including water supply projects, scholarships and so on, which, in many cases, point to wider social gains.

Finally, remittances are used for a variety of social purposes, including the high costs of weddings, funerals and other ceremonies, but also the costs of education (which may lead to long-term economic gains). It is particularly through these kinds of social expenditure that migrants emphasise their continued stake in and commitment to the home society. Indeed much of the literature on migration, by emphasising the more obvious economic effects of remittances, has neglected their massive social significance. Walker and Brown's [17] estimates for the Tongans and Samoans in the 1994 study, thus including the nurses, suggest that "social uses" were considered the main use of remittances by $79 \%$ and $63 \%$ of households, respectively. Overall nearly $10 \%$ of remittances were used for such purposes.

As better and more reliable survey data, such as those reported in these papers emerge, and, as the emergence of the Nuku'alofa flea market has demonstrated, there is strong evidence of an evolution in use from consumption to investment. If remittances constitute an important part of total household income it can be expected that they also have a significant impact on the distribution of household income, unless it is believed that the distribution of remittance income is the same as the distribution of income from all other sources. There is no consensus on whether remittances improve or worsen the distribution of income. This is not altogether surprising given the variety of forms, channels and uses of remittances, formal and informal, and the resulting paucity of quality data on household income and expenditure. However, until recently the dominant view was that remittances were likely to reinforce income inequality, by enhancing the capacity of the recipient households to invest in additional migration, education and other income-generating assets [55,45]. Recent empirical studies based on survey data challenge this view. From independent data sources, Ahlburg [45] and Brown and Connell [57] found that the distribution of household income with remittances was less skewed than the distribution without remittances.

\section{Conclusions}

For more than a quarter of a century there has been substantial emigration from the smaller island states of the Pacific to metropolitan fringe states, mainly the USA, New Zealand and Australia. Migration reduced unemployment in island states, but also involved a skill drain, and remittances have contributed to raised living standards. In states such as Tonga and Samoa there has been some shift of remittances from consumption to investment. Communal remittances are of greater significance than in other world regions. There is a high propensity to sustain remittance flows over long periods of time at some cost to the senders. The duration and magnitude of migration, the remittance flows and their considerable social and economic consequences in a range of contexts have demonstrated the need for much more attention to be given, 
in terms of both studies and policy formation, to the role of migration and remittances in economic and social development in the Pacific region. This study has examined one facet of this relationship - the extent of remittances amongst migrant nurses in Samoa and Tonga - and the relationship between this and the structure of the health care system.

The key conclusions of the study are that, first, nurses are more likely to be remitters and remit larger amounts than other migrants. It is beyond the scope of this study to calculate, as Goldfarb et al [8] did, the extent to which nurse remittances are sufficient to cover the private and social costs of their training, but there is clear evidence from the remittance behaviour described here that the transfer income equivalent to US $\$ 2,688$ per annum would certainly exceed the initial investment in their human capital. The higher remittance propensity of nurses is also consistent with other studies that have concluded that women migrants are more frequent and more generous remitters than men. Moreover, nurses appear to be more altruistic, at least in terms of their decision to enter the profession, and may also be more responsive to perceived need of kin, and hence their greater likelihood to remit and the higher absolute levels of remittances.

Second, although nurses remit more per capita, they are ultimately less generous than the others in terms of the proportion of their income that they remit, and this proportion falls steadily as their income level increases. This need not be interpreted as wealthier nurses being less altruistically inclined than others, but simply reflects a similar phenomenon to target saving, where, in the case of remittances, once a migrant has achieved a certain target level of family support, remittances no longer rise with income. This would explain why remittances as a proportion of income eventually begin to decline at higher income levels. The fact that nurses are more likely to be owners of real estate and other assets in Tonga and Samoa suggests that there could be also a significant element of self-interest, which would also explain the upward turn in the remittance function where remittances are measured against length of absence, and where that length is greater than 20 years.

Third, as has been shown, after controlling for income and all other variables nurses remittances do not decrease with duration of absence, unlike other groups whose remittances decline markedly as their length of absence increases. This is a major new finding following this split analysis of the 1994 sample, given that all other econometric evidence produced no evidence of decay; or for that matter of any significant relationship between remittances and duration of absence. Disaggregating the same data into two sub-groups, nurses and others, has shown that there is a strong but qualitatively different relationship between remittances and duration of absence. As previously noted, the positive (quadratic) relationship between remittances and length of absence for nurse households could reflect either sustained altruism, or, increased self interest in remitting as migrant nurses become older, and contemplate return migration: the so-called 'nest egg' factor.

Fourth, nurse households are more likely to possess the other remittance-promoting characteristics identified by this study; namely, the ownership of land and other assets at home, continued personal contact with kin in the home country, and the intention to return home. This concurs with the conclusions of a wider contemporary study of the migration of skilled health workers in the region that migration was less likely to occur when these workers owned a house or business in the home country. Moreover returning health workers were particularly likely to establish a business on their return [24]. Consistent with this finding, the data from the present study suggest that nurses may be sending back larger volumes of remittances as they seek to construct or improve houses or set up businesses in the home country. This further suggests that their intent to return may become a reality, despite their longer stay overseas. Thus the nurses' skills may not be entirely lost to the home country. Indeed, they are most likely to have acquired additional human capital abroad which is then transferred to the home country.

Together, these findings go some way towards explaining the observation from the descriptive statistics (shown in Figures 1 and 2) that nurse household's remittance levels are higher than others. While a larger study of migration of health workers from the region indicated that there were some gains to migration in that many health workers returned from overseas with additional skills and with capital that was invested in housing and businesses, thus providing both individual and national benefits [24], the present study has further emphasized these conclusions. It has shown that remittance flows from nurses are very considerable and may well be contributing to a situation that does enable business development, and at the same time increases the likelihood the nurses will eventually return.

Overall therefore this suggests that the loss of skilled health workers, at least in the case of Tongan and Samoan nurses, is not a wholly negative phenomenon. Their remittances contribute to broadly based development in the home country - at a time when other facets of local economies are struggling - and have some positive impact on the health sector. Moreover they contribute to a situation where there are incentives, in terms of businesses and improved housing stock, to encourage return migration, and they may themselves return. 
Migration occurs in a context where a number of metropolitan governments have implemented aggressive recruitment campaigns to attract doctors and nurses, a situation evident by the 1960 s and increasingly becoming a global phenomenon $[6,58]$. Attempts to slow that migration in the Pacific region have focused on developing primary health care services, establishing regional and national medical schools and other training facilities, adapting medical curricula to local needs and enabling private practice (and thus greater opportunities for local income generation). Despite such policies migration has continued, especially where skilled health workers graduated or went for further training overseas, and in the absence of significantly higher wages (an impossibility for PICs), improved working conditions, growing perceptions of superior salaries and conditions overseas, and through recruitment, in a context where international migration was a familiar and accepted phenomenon.

While the present study has not addressed these questions, it is evident that a skill drain is likely to continue, where there have been structural reforms that reduce public sector employment, wages and salaries remain unequal, working conditions are difficult and hierarchical, international recruitment intensifies and many kin are overseas [24]. Policies that redress most of these circumstances have proved difficult for small and poor PICs. However the present study emphasizes that the skill drain has some potential gains through human capital transfers (with return migration), remittances and the investments of returnees. Hence policy formation concerning skilled health workers might also focus on encouraging return migration, through providing appropriate investment opportunities $[10,59]$ and more adequate working conditions and promotion structures. However, even were this to be achieved, international migration would be highly likely to continue though the impact would be less negative.

Finally, over the decade since the data on remittances for this study were collected, the shortage of nurses in Australia and New Zealand has significantly worsened, leading to more active recruitment in, and greater migration of nurses from, Tonga and Samoa. As migration to Australia and New Zealand has also become more selective by skills, it is therefore probable that nurses have come to represent an even larger proportion of the total migrant outflow from these countries, with the consequent increase in both the proportion of migrant households sending remittances, and the average level of household remittances. In conjunction with a study of the private and public sector costs of educating and training nurses, it would be useful to re-survey the migrant nurse households in Australia and also in New Zealand with a view to undertaking a more rigorous cost-benefit analysis of human capital investment in nurse training.

\section{Competing interests}

None declared.

\section{Authors' contributions}

While the paper was written jointly, RB carried out the econometric analysis.

\section{Acknowledgements}

The authors wish to acknowledge financial support from WHO for preparing the research report on which this paper is based.

\section{References}

I. Dilip R: Workers' remittances: An important and stable source of external development finance. Global Development Finance 2003. Chapter 7 Washington DC: The World Bank; 2003.

2. Kapur D, McHale J: Migration's new payoff. Foreign Policy 2003, 48:49-57.

3. Forsyth DJC: Migration and remittances in the South Pacific Forum island countries. Monograph. Suva, Fiji: Department of Economics, University of the South Pacific 1992.

4. Macpherson C: Economic and political restructuring and the sustainability of migrant remittances: the case of Western Samoa. The Contemporary Pacific 1992, 4:109-136.

5. World Bank: Health Priorities in the World Banks Pacific Member Countries Washington DC: World Bank; 1994.

6. Mejia A, Pizurki H, Royston E: Physician Migration and Nurse Migration. Analysis and Policy Implications Geneva: World Health Organization; 1979.

7. Commonwealth Secretariat: Migration of Health Workers from Commonwealth Countries London: Comm Sec; 2001.

8. Goldfarb R, Havrylshyn O, Mangum S: Can remittances compensate for physician outflows? The case of Philippine physicians. Journal of Development Economics 1984, I5: I-17.

9. Bilsborrow RE, Oberai AS, Standing G: Migration Surveys in Low Income Countries: Guidelines for Survey and Questionnaire Design London: Croom Helm; 1984.

10. Brown RPC: Estimating remittance functions for Pacific island migrants. World Development 1997, 25:613-626.

II. Brown RPC: Do migrants remittances decline over time? evidence from Tongans and Western Samoans in Australia. The Contemporary Pacific 1998, 10:107-151.

12. Brown RPC, Connell J: The global flea market: migration, remittances and the informal economy in Tonga. Development and Change 1993, 24:6 II-647.

13. Brown RPC: Migrants' remittances, savings and investment in the South Pacific. International Labour Review 1994, 133:347-367.

14. Brown RPC: Hidden foreign exchange flows: estimating unofficial remittances to Tonga and Western Samoa. Asian and Pacific Migration Journal 1995, 4:35-54.

15. Brown RPC, Walker A: Migrants and their remittances: results of a household survey of Tongans and Western Samoans in Sydney. Pacific Studies Monograph. No. I 7. Centre for South Pacific Studies, Sydney: University of New South Wales 1995.

16. Brown RPC: Consumption and investments from migrants' remittances in the South Pacific. International Migration Papers. No.2. Employment Department, International Labour Office, Geneva: ILO 1995.

17. Walker AM, Brown RPC: From consumption to savings? interpreting Tongan and Western Samoan sample survey data on remittances. Asian and Pacific Migration Journal 1995, 4:89-116.

18. Lucas REB, Stark O: Motivations to remit: evidence from Botswana. Journal of Political Economy 1985, 93:901-918.

19. Tongamoa T: Migration, remittances and development: a Tongan perspective. Unpublished MA Thesis, University of Sydney 1987.

20. Grieco EM: The Remittance Behaviour of Immigrant Households: Micronesians in Hawaii and Guam LFB Publishing; 2003.

21. Vete MF: The determinants of remittances amongst Tongans in Auckland. Asian and Pacific Migration Journal 1995, 4:55-68. 
22. Stanwix $C$, Connell $\mathrm{J}$ : To the islands: the remittances of Fijians in Sydney. Asian and Pacific Migration Journal 1995, 4:69-88.

23. Loomis T: Cook Island remittances: volumes, determinants and uses. In Migration and Development in the South Pacific. Pacific Research Monograph No. 24. Canberra: National Centre for Development Studies, Australian National University 1990:6I-8I.

24. Connell J: The migration of skilled health personnel in the Pacific Region. Unpublished Report. Geneva: World Health Organization 2003.

25. Marcus GE: Power on the extreme periphery: the perspective of Tongan elites in the modern world system. Pacific Viewpoint 1981, 22:48-64.

26. Bertram G: Sustainable development in South Pacific microeconomies. World Development 1986, 14:809-822.

27. Gailey CW: State formation, development and social change in Tonga. In Social Change in the Pacific Islands Edited by: Robillard A. London: Kegan Paul International; 1992:322-345.

28. Cowling W: Motivations for contemporary Tongan migration. In Tongan Culture and History Edited by: Herda P, Terrell J, Gunson N. Canberra: Australian National University; 1990:187-205.

29. James KE: Migration and remittances: a Tongan village perspective. Pacific Viewpoint 1991, 32:1-23.

30. Stark O: The Migration of Labor Basil Blackwell: Oxford; |99|.

31. Stark O: Migration in LDCs: risk, remittances, and the family. Finance and Development 1991, 28:39-4I.

32. Hayes G: Migration, metascience, and development policy in Island Polynesia. The Contemporary Pacific 1991, 3:1-58.

33. Hoddinott : Modelling remittance flows in Kenya. Journal of African Economies 1992, 1:206-232.

34. Poirine B: A theory of remittances as an implicit family loan arrangement. In Two Essays on Aid and Remittances. Pacific Studies Monograph No. 19. Centre for South Pacific Studies. Sydney: University of New South Wales 1995.

35. Brown RPC, Poirine B: Intergenerational transfers with impure altruism: an analysis of migrants' remittance. Discussion Papers. No. 224. Department of Economics, The University of Queensland, Brisbane 1997.

36. Piore MJ: Birds of Passage: Migrant Labour and Industrial Societies Cambridge: Cambridge University Press; 1979.

37. Quibria MG, Thant M: International labor migration, emigrants' remittances, and Asian developing countries: economic analysis and policy issues. In Research in Asian Economic Studies Edited by: Dulta M. Greenwich, Connecticut: Jal Press; 1988.

38. Amjad R: Impact of workers' remittances from the Middle East on Pakistan's economy: some selected issues. The Pakistan Development Review 1986, 25:757-782.

39. Macpherson C: Changing patterns of commitment to island homelands: a case study of Western Samoa. Pacific Studies 1994, 17:83-116.

40. Diaz-Briquets S, Weintraub S: Migration, Remittances, and Small Business Development: Mexico and Caribbean Basin Countries Boulder: Westview Press; 1991.

41. Helweg AW: Emigrant remittances: their nature and impact on a Punjab village. New Community 1983, 10:435-443.

42. Foster J: The relationship between remittances and savings in small Pacific island states: some econometric evidence. Asian and Pacific Migration Journal 1995, 4: I I7-I 38.

43. Shankman P: Migration and Underdevelopment: The Case of Western Samoa. Boulder: Westview 1976.

44. Brown RPC, Foster J, Connell J: Remittances, savings, and policy formation in Pacific island states. Asian and Pacific Migration Journal 1995, 4:169-185.

45. Ahlburg D: Remittances and their impact: a study of Tonga and Western Samoa. Pacific Policy Papers. No.7. Canberra: National Centre for Development Studies, Australian National University I99I.

46. Connell J: Migration and development in the South Pacific. Pacific Research Monograph. No.24. Canberra: National Centre for Development Studies, Australian National University 1990.

47. Miles R, Alam M, Wickramasekara P, Larhed T: Employment in Tonga: Present and Potential. Suva, Fiji: ILO/UNDPIAIDAB 1992

48. Marcus GE: Tonga's contemporary globalizing strategies: trading on sovereignty amidst international migration. In Contemporary Pacific Societies Edited by: Harding T, Wallace B. Englewood Cliffs: Prentice Hall; 1993.

49. Campbell IC: A historical perspective on aid and dependency: the case of Tonga. Pacific Studies 1992, 15:59-75.
50. Commonwealth of Australia (COA): Australia's Relations with the South Pacific Canberra: Australian Government Publishing Service; 1989.

51. Organisation for Economic Co-operation and Development. The Future of Migration. Paris 1987.

52. Standing G: Income transfers and remittances. In Migration Surveys in Low Income Countries: Guidelines for Survey and Questionnaire Design Edited by: Bilsborrow RE, Oberai AS, Standing G. London: Croom Helm; 1984.

53. Faeamani S: The impact of remittances on rural development in Tongan villages. Asian and Pacific Migration Journal 1995, 4:139-156.

54. World Bank: Pacific Island Economies: Toward Efficient and Sustainable Growth Volume I, 6 \& 8. Washington, DC: The World Bank; 1993.

55. Connell J: Remittances and rural development: migration, dependency and inequality in the South Pacific. Occasional Paper. No.22. Canberra: National Centre for Development Studies, Australian National University 1980.

56. Tongamoa T: International migration, remittances and Tonga. Review 1990, 18:12-18.

57. Brown RPC, Connell J: Migration and remittances in Tonga and Western Samoa. Report prepared for the ILO, Geneva Brisbane: The University of Queensland; 1993.

58. Hardill I, MacDonald S: Skilled international migration: the experience of nurses in the United Kingdom. Regional Studies 2000, 34:68I-692.

59. Ahlburg A, Brown RPC: Migrants' intentions to return home and capital transfers: a study of Tongans and Western Samoans in Australia. Journal of Development Studies 1998, 35:125-15I.

Publish with Bio Med Central and every scientist can read your work free of charge

"BioMed Central will be the most significant development for disseminating the results of biomedical research in our lifetime. "

Sir Paul Nurse, Cancer Research UK

Your research papers will be:

- available free of charge to the entire biomedical community

- peer reviewed and published immediately upon acceptance

- cited in PubMed and archived on PubMed Central

- yours - you keep the copyright

Submit your manuscript here:

http://www.biomedcentral.com/info/publishing_adv.asp
BioMedcentral 